Acta vet. scand̀. $1976,17,412-425$.

From the State Veterinary Research Station for Small Ruminants, Höyland, Sandnes, Norway.

\title{
TOXOPLASMOSIS IN SHEEP
}

THE RELATIVE IMPORTANCE OF THE INFECTION AS A CAUSE OF REPRODUCTIVE LOSS IN SHEEP IN NORWAY*

By

\section{Harald Waldeland}

WALDELAND, H.: Toxoplasmosis in sheep. The relative importance of the infection as a cause of reproductive loss in sheep in Norway. Acta vet. scand. 1976, 17, 412-425. - The importance of toxoplasmosis as a cause of reproductive loss was examined during the period 1968-1973, based on diagnostic materials submitted from 126 flocks. Toxoplasmosis was diagnosed in 81 of these. Reliable information of the number of breeding ewes and their reproductive performance was obtained from 117 flocks, where 858 of 7812 breeding ewes failed to produce viable lambs. About $80 \%$ of the total loss in these flocks was attributed to toxoplasmosis, $4 \%$ to bacterial infections, and $16 \%$ to non-infectious and/or unidentified causes.

The frequency of loss within individual flocks was higher from toxoplasmosis than from any other cause, reaching a maximum of $78 \%$ of the breeding ewes. In 21 of 42 flocks of at least 20 breeding ewes and a high frequency of loss $(\geq 10 \%)$ from toxoplasmosis, $20 \%$ or more of the ewes lost their lambs, whereas a loss of this order only occurred in 1 of the 13 flocks in which some other diagnosis was made.

In addition to abortion, toxoplasmosis was also associated with returns to service, barrenness, stillbirth, and delivery of weak lambs that died soon after birth.

White spots were observed on the cotyledons of nearly $2 / 3$ of the placentas expelled from toxoplasmosis. No evidence was found that these changes occurred in any other disease.

The incidence of abortion was higher among young ewes than among the older ones. No clinical symptoms of infection were observed prior to abortion from toxoplasmosis, and the ewes kept for breeding behaved normally in later pregnancies.

toxoplasma infection; reproduction in sheep; abortion; sheep.

* This work was supported by grants from The Norwegian Research Council for Science and for the Humanities. 
Toxoplasmosis is a common cause of abortion and neonatal death in sheep in many countries. In England $18-20 \%$ of the "outbreaks" of abortion have been attributed to this infection (Beverley \& Mackay 1962, Beverley \& Watson 1962), in Tasmania $46 \%$ (Munday 1970), and in New Zealand $74 \%$ (Hartley \& Boyes 1964). Investigations by Waldeland \& Øverås (1968) showed that abortions from infection with Toxoplasma gondii occur in sheep also in Norway. The intention of the present work was to elucidate the relative importance of toxoplasmosis as a cause of reproductive loss in sheep in Norway, based on diagnostic materials submitted to this laboratory during a period of 6 years.

\section{MATERIALS AND METHODS}

The investigation was carried out during the period 19681973, and comprised 126 different flocks. Examinations were requested in 122 flocks because of abortion, in 1 flock because of repeat breeding at 2-3 months of assumed pregnancy, and in 3 flocks because of stilliborn lambs or weak lambs that died soon after birth. In a total of 11 flocks examinations were requested during more than 1 lambing season, i.e. during 2-4 seasons. Reliable information on the number of breeding ewes and their reproductive performance was obtained from 117 f locks. The materials examined are recorded in Table 1.

The blood samples listed in Table 1 were from ewes that were

Table 1. Diagnostic materials from 126 flocks of sheep.

\begin{tabular}{ccc}
\hline \multicolumn{3}{c}{ Number of } \\
\hline flocks & $\begin{array}{c}\text { ewes from which placentas, } \\
\text { foetuses or dead lambs } \\
\text { were examined }\end{array}$ & $\begin{array}{c}\text { sheep examined } \\
\text { serologically }\end{array}$ \\
\hline 42 & 63 & - \\
$56^{\star}$ & 106 & 629 \\
28 & - & 157 \\
\hline 126 & $169^{\star \star}$ & $786^{\star \star \star}$ \\
\hline
\end{tabular}

* From each of these flocks both blood samples and placentas, foetuses or dead lambs were examined.

* * From these ewes a total of 74 placentas and 225 foetuses, stillborn lambs or lambs that died within $24 \mathrm{hrs}$. of delivery were examined.

** 314 were from ewes that lambed normally. 
barren, aborted or were presumed to have aborted, delivered dead lambs or lambs that died within 24 hrs. of delivery, and from ewes with a normal pregnancy selected at random in some of the flocks. Due to difficulties in identifying the individual ewes from which aborted materials were found in some of the flocks, the identity of some of the ewes from which both blood samples and aborted materials were examined was not established.

Most of the flocks were from the western and the southwestern Norway; only 1 flock was from the northern and 1 from the eastern part of the country.

\section{Laboratory examinations}

Besides gross inspection of the aborted materials and the dead lambs, examinations for $T$. gondii and other microorganisms were routinely carried out.

Examination for T. gondii. Suspensions were made in physiological saline both of foetal brains and of cotyledons in a reasonable state of preservation, and each of 5-6 mice were inoculated subcutaneously with $1.0-1.2 \mathrm{ml}$ of each suspension. The preparation of the suspensions and the later examination of the mice brains were mainly done as described by Beverley \& Watson (1961). Prior to the inoculation and immediately before they were killed, the mice were bled from the sino-orbital plexus by means of microhaematocrit tubes, and their sera were examined for Toxoplasma antibodies.

Examination for other microorganisms. The abomasal contents were routinely examined at $320 \times$ with a phase contrast microscope. Cultures from brain, lung, heart, liver, and abomasal contents were made on $7 \%$ sheep blood agar and incubated aerobically at $37^{\circ} \mathrm{C}$ for $48 \mathrm{hrs}$. From small and partly mummified foetuses only the brain and the abdomen were examined bacteriologically. Abomasal contents were also inoculated into thiol medium (Difco ${ }^{\star}$, Bacto thiol medium, 0307-02) and incubated at $37^{\circ} \mathrm{C}$ in an atmosphere that contained $10 \% \mathrm{CO}_{2}$, and the tubes were examined after 4, 7 and 10 days. Cultures from brains were also made on tryptose agar (Difco, Bacto tryptose agar, 0064-01) and tryptose broth (Difco, Bacto tryptose broth, $0062-01$ ) at $37^{\circ} \mathrm{C}$, and on semisolid agar (meat extract broth with $0.30 \%$ agar) at room temperature for $48 \mathrm{hrs}$. Smears from

\footnotetext{
* Difco Laboratories Inc., Michigan, USA.
} 
cotyledons from most of the placentas were stained by a modified Ziehl-Neelsen technique (Stamp et al. 1950) and examined for the elementary bodies of the agent of enzootic abortion and for Coxiella burnetii.

Serological examination. The serum samples were examined for Toxoplasma antibodies by a micromodification of the Sabin \& Feldman (1948) dye test (DT) as described by Waldeland (1976 a). The sera were stored at $-20^{\circ} \mathrm{C}$ until the examination.

Criteria for the diagnosis of toxoplasmosis. A positive diagnosis from examination of aborted materials or dead lambs was made if cysts were found in at leasit 1 of the inoculated mice, and the identity of these cysts as $T$. gondii was confirmed by detection of Toxoplasma antibodies in the mice sera. A positive diagnosis based on serological examination alone was made if a DT titre of $\leq 1 / 512$ was found (Waldeland $1977 \mathrm{a}$ ).

\section{RESULTS}

The causes of abortion, stillbirth or neonatal death were demonstrated in 77 of the 169 ewes by examination of conceptas and dead lambs, and by serological examination a diagnosis was made in an additional 29 of these.

\section{Aetiology}

Toxoplasmosis. T. gondii was recovered from materials from 63 of the 169 ewes, and in addition, toxoplasmosis was also diagnosed in 29 of the remaining 106 by serological examination. A positive diagnosis based on serology was made in a total of 178 ewes, 49 of which were from flocks examined only by the DT. Titres $\geq 1 / 512$ were also found in 13 ewes with a normal pregnancy, 3 of which were from 2 flocks with abortions from unidentified causes. The infection was found as cause of reproductive loss in a total of 81 of the 126 flocks listed in Table 1 . The diagnosis was based on detection of T. gondii in 30 flocks, in 23 flocks both on detection of $\mathrm{T}$. gondii and on serological examination, and in 28 flocks on the DT alone. From 20 of the latter flocks, only blood samples were examined.

Listeriosis. Listeria monocytogenes was isolated from the foetuses of 3 ewes from 3 different flocks. In 2 of these flocks abortions from toxoplasmosis were also diagnosed.

Vibriosis. Campylobacter (Vibrio) foetus was recovered from 
the foetuses from 3 ewes from 2 flocks. In 1 of these flocks the infection was diagnosed twice with an interval of 2 years.

Salmonellosis. Salmonella montevideo was isolated from the foetuses of 3 ewes from the same flock. This flock was examined by Hortemo \& Øverås (1968), and the bacterium was typed by Kristiansen (1968).

Corynebacterium pyogenes infection. C. pyogenes was the only organism isolated from the foetus of 1 ewe in a flock where several other ewes aborted from toxoplasmosis.

Bacillus-spp. infection. A great number of nonmotile rods was observed by phase contrast microscopy of the abomasal contents of 3 foetuses from the same ewe. The morphology, growth requirements and characteristics, and biochemical properties indicated that the organism belonged to the genus Bacillus, but it could not be identified as B. cereus, B. subtilis, B. licheniformis or B. megaterium. Two years later a similar bacterium was isolated from 2 foetuses submitted from the same flock.

Goitre. A greatly enlarged thyroid gland was observed in 1 lamb submitted from a flock where a total of 5 ewes delivered dead lambs or lambs that died shortly after birth. The owner observed that all lambs born to these ewes had swollen necks.

Malformations. Lethal deformities of the cardiovascular system were found in 1 lamb from a flock where some lambs were aborted from toxoplasmosis and others from unexplained causes.

Not diagnosed. The causes of loss were not identified in a total of 39 flocks, and in addition in 18 ewes from 6 flocks where some loss from identified causes also occurred.

\section{Losses}

In the 117 flocks from which reliable information was obtained, a total of 858 ewes failed to produce live lambs or delivered lambs that died soon after birth. The frequencies of the causes to which this loss was ascribed are recorded in Table 2.

In 7 of the 9 flocks from which reliable information on the reproductive performance was not obtained, the causes of loss were not identified, whereas in the 2 other flocks the loss was caused by toxoplasmosis.

Rate of loss. The annual rate of loss attributed to toxoplasmosis ranged from 68 to $89 \%$ of the total during the 6-year period, whereas for other infections the annual rate varied be- 
T a b l e 2. Frequency of causes of foetal injury during 1968-1973 in 858 ewes from 117 flocks. Every ewe which lost all the lambs from foetal disease is recorded under the diagnosis made for the flock, although not each individual which lost its lambs was examined. The number of breeding ewes each year in 11 flocks from which materials were received during more than 1 year are added, giving the total number of pregnancies.

\begin{tabular}{|c|c|c|c|c|c|}
\hline \multirow[b]{2}{*}{ Diagnoses } & \multicolumn{4}{|c|}{ Number of } & \multirow[b]{2}{*}{$\begin{array}{l}\text { Percentage } \\
\text { of the total } \\
\text { loss }\end{array}$} \\
\hline & \multicolumn{2}{|c|}{ flocks } & $\begin{array}{l}\text { breedings } \\
\text { ewes }\end{array}$ & $\begin{array}{c}\text { ewes with } \\
\text { reproductive } \\
\text { loss }^{\star}\end{array}$ & \\
\hline Toxoplasmosis & 72 & (1) & 4348 & 617 & 71.9 \\
\hline More than one diagnosis & & & & & \\
\hline in the same flock & 7 & (7) & 1659 & $92^{\star \star}$ & 10.7 \\
\hline Vibriosis & 2 & (1) & 107 & 16 & 1.8 \\
\hline Listeriosis & 1 & & 50 & 1 & 0.1 \\
\hline Salmonellosis & 1 & & 100 & 10 & 1.2 \\
\hline Bacillus-spp. infection & 1 & (1) & 28 & 4 & 0.5 \\
\hline Goitre & 1 & & 10 & 5 & 0.6 \\
\hline Not established & 32 & (1) & 1510 & 113 & 13.2 \\
\hline Total & 117 & (11) & 7812 & 858 & 100.0 \\
\hline
\end{tabular}

Figures in brackets: Number of flocks from which materials were examined during more than 1 lambing season.

* Abortion or presumed abortion, stillbirth, and delivery of weak lambs that died.

* * Seventy of these aborted from toxoplasmosis, 2 from listeriosis, 1 from Corynebacterium pyogenes infection, 1 from malformations of the foetus, and 18 from unexplained causes.

tween 1 and $11 \%$. The rate of loss was highest in the flocks in which toxoplasmosis was diagnosed, and affected a maximum of $78 \%$ of the breeding ewes. The diagnoses made in flocks of at least 20 breeding ewes in which there were major losses are reconded in Table 3. About $2.5 \%$ of the ewes delivered 1 dead, often decomposed lamb, and 1 lamb that survived, both in flocks with toxoplasmosis and in flocks with losses from unexplained causes.

Lambs with poor viability. In 3 flocks with no abortion several sheep delivered dead or weak lambs that died soon after birth. T. gondii was the only pathogen detected in 2 of these flocks; in the third flock the condition was associated with goitre. Deliveries at full term of dead or weak lambs also occurred in some flocks where abortion was the main problem. 
T a b l e 3. Diagnoses made in 55 flocks of at least 20 breeding ewes, with rates of reproductive loss $\geq 10 \%$ in each flock.

\begin{tabular}{lrrr}
\hline \multirow{2}{*}{ Diagnoses } & \multicolumn{3}{c}{ Number of flocks } \\
\cline { 2 - 4 } & \multicolumn{2}{c}{ rate of loss $(\%)$} & total \\
\cline { 2 - 4 } & $10-19$ & 20 & \multirow{2}{*}{$\begin{array}{l} \\
\text { Toxoplasmosis }\end{array}$} \\
Bacterial infections & 21 & 21 & 3 \\
Not established & 3 & 10 & 10 \\
\hline Total & 9 & 1 & 55 \\
\hline
\end{tabular}

Post-mortem examination

Foetuses and lambs. Some lambs had died after birth, while the gross appearance of others indicated that they had died up to several weeks before they were expelled. No difference in the gross appearance was found between decomposed foetuses aborted from toxoplasmosis and decomposed foetuses aborted from other causes. In a few of the not visibly decomposed foetuses there was an excess of clear, slightly yellowish fluid in the body cavities, sometimes with strands of fibrin. Some foetuses had a few petecchial haemorrhages on the pulmonary pleura. The liver was often friable, slightly swollen and rounded at the edges. In 12 of 49 well preserved foetuses or lambs aborted or dead from toxoplasmosis there was rupture of the liver and blood clots in the abdomen. T. gondii was recovered from all of these 12 lambs, 8 of which had died shortly before and 4 after birth at full term. Of 35 well preserved lambs in which toxoplasmosis was not diagnosed, liver rupture was only found in a twin couple.

Foetal membranes. Fifty of the 74 placentas were from ewes with toxoplasmosis. The cotyledons in these 50 placentas were often firm and pale pink, and in some cotyledons of 33 of them (66\%) there were white nodules up to $2 \mathrm{~mm}$ in diameter. White nodules were also observed in 3 of 24 placentas (12\%) expelled from bacterial infections or unexplained causes.

\section{The ewes}

The majority of the ewes aborted during the last month of gestation. There was no noteworthy difference in time of abortion between the flocks with toxoplasmosis and the remainder.

Age of the ewes that aborted. In 15 of 59 flocks where at least 
5 abortions occurred, $1-2$ years old ewes were mainly affected. The abortions were caused by toxoplasmosis in 14 of these flocks, and in 1 flock by an unidentified cause. In the 44 other flocks the frequency of abortion was mainly the same within all age groups.

Returns to service. Excessive rates of returns to service at irregular intervals within 2 months after the first mating were observed in 5 flocks, and in 1 flock at about 3 months of assumed pregnancy. In the latter, 30 of 58 ewes returned to service. Several ewes in this flock had DT titres $\geq 1 / 512$, and the only evidence of foetal death was vaginal discharges from a few of them. In 4 of the other 5 flocks some ewes aborted from toxoplasmosis, and in 1 flock from unexplained causes. As well excessive returns to heat as a high number of barren ewes (about $15 \%$ ) were reported in 1 of the flocks with abortions from toxoplasmosis.

Barrenness. More than $10 \%$ of the ewes were barren in 4 flocks with abortions from toxoplasmosis and in 1 flock with abortions from unexplained causes. Each of these flocks comprised 45 or more breeding ewes.

Clinical observations. The 10 ewes infected with S. montevideo showed distinct symptoms of illness both before and after the abortion, and 4 of them died. Otherwise, clinical symptoms were not observed before the abortion whatever the cause. After abortion a few ewes were treated for secondary uterine infection associated with retention of the placenta.

\section{Repeated occurrence of reproductive loss in the same flock}

One or 2 abortions occurred nearly each year in the majority of the flocks. In 2 flocks with Toxoplasma abortions and in 1 flock with unexplained abortions there were histories of unexpectedly high reproductive loss the preceding year.

In the 11 flocks from which materials were received during $2-4$ seasons, 135 abortions occurred among a total of 2206 pregnancies. The same pathogen was found in different years in 4 of these flocks. In 1 flock it was Bacillus-spp., in 1 flock C. (Vibrio) foetus, and in 2 flocks T. gondii. In the latter 2 flocks a total of 20 abortions occurred among 607 pregnancies.

Ewes not slaughtered after abortion from toxoplasmosis behaved normally during the subsequent pregnancy. 


\section{DISCUSSION}

As recorded in Table 1, blood samples were also examined from ewes with a normal pregnancy. This was done to support the diagnosis in case of toxoplasmosis, although a positive flock diagnosis was never based solely on high titres $(\geq 1 / 512)$ in ewes with a normal pregnancy.

Toxoplasmosis was found as cause of loss in about $54 \%(92$ of 169) of the ewes from which aborted materials or dead lambs were submitted, but as can be deduced from Table 2 about $80 \%$ of the total loss was attributed to this infection, even though every ewe which lost its lambs was not examined. However, as the rate of loss in individual flocks was higher from toxoplasmosis than from any other cause (Table 3), the percentage of loss from this infection as estimated in Table 2 seems reasonable. This estimation was also supported by extensive serological examinations in 47 flocks in which toxoplasmosis was diagnosed, where a total of 495 ewes lost their lambs. In 7 of these flocks 22 of 92 ewes aborted from other causes than toxoplasmosis (Table 2), but only in 4 individual cases during the same lambing season when toxoplasmosis was diagnosed. Most of the other ewes that lost their lambs in the 47 flocks had higher titres than usually observed in sheep with a latent infection (Waldeland 1977 a), i.e. in the range $1 / 128-1 / 8192$.

It should be noted that high titres were also found in ewes with a normal pregnancy from 2 flocks with abortions from unidentified causes. Although serological evidence of infection (DT titres $\geq 1 / 16$ ) was found in ewes that aborted in these flocks, their titres were not high enough to established a positive diagnosis of toxoplasmosis as a cause of abortion. According to studies of experimental toxoplasmosis in sheep (Watson \& Beverley 1971), high titres may be found in ewes with a normal pregnancy infected during the last month before lambing, while ewes that abort from infection during mid-pregnancy on some occasions may have low titres. It is therefore possible that the total loss from this infection in the present investigation was higher than estimated in Table 2.

The other identified causes of abortion were responsible for less than $5 \%$ of the total loss. It is possible that the incidence of listeric abortion is higher in counties in Norway where listeric encephalitis occurs more frequently, and that the rate of bac- 
terial abortions may vary because of fluctuations in the incidence of vibriosis as recorded from England (Watson 1962 a).

The rate of loss associated with toxoplasmosis was high in individual flocks. As shown in Table 3, 21 of 42 flocks with at least 20 breeding ewes had a rate of loss $\geq 20 \%$, whereas a rate of loss of the same order was observed in only 1 of the 13 flocks in which some other diagnosis was made. There are few other reports on the rate of loss associated with toxoplasmosis, but in an investigation from Yorkshire Beverley \& Watson (1962) found a mean abortion rate of $9 \%$ in 16 flocks comprising 1928 ewes, and in 3 of the flocks more than $20 \%$ of the ewes aborted. This indicates that the infection during the period 1968-1973 in Norway had greater consequences for the affected flocks than earlier recorded in England, although the difference is not statistically significant.

The time of abortion in relation to the expected lambing date was generally the same irrespective of the diagnosis. Although there was a higher frequency of foetuses that had been dead for some time among those aborted from toxoplasmosis, the difference was not statistically significant.

The gross appearance of foetuses dead from this infection was mainly as described by Hartley \& Kater (1963) and Beverley et al. (1971 b). However, it is remarkable that there was a higher incidence of liver rupture among lambs with congenital toxoplasmosis than among lambs idead from other causes $(P \approx 0.05$, chi-square test). In the present investigation liver rupture was observed in $1 / 4$ of the well preserved lambs with congenital toxoplasmosis, and in this connection it is interesting to note that Hartley \& Kaler and Beverley et al. (1971 b) found granulomas in the liver of about $1 / 3$ of the infected lambs. The death of newborn lambs with ruptured livers is usually ascribed to trauma if the bacteriological examination is negative. The present findings suggest that such lambs also should be examined for $\mathrm{T}$. gondii.

The macroscopic changes in the foetal membranes associated with toxoplasmosis were also mainly as described by Hartley $\&$ Kater and Beverley et al. (1971 a). The characteristic white spots were also found in 3 of the 24 placentas expelled from other or not explained causes. However, because of insufficient material for examination, the possibility of toxoplasmosis was not entirely ruled out in any of the 3 cases. Similar changes have apparently not been described in any other disease. The high frequency of 
such lesions associated with toxoplasmosis as demonstrated in the present investigation may therefore be of great diagnostic importance.

The large number of barren ewes in 4 flocks with Toxoplasma abortions might have been caused by infection at an early stage of pregnancy, resulting in resorption of the foetuses as observed by Jacobs \& Hartley (1964). Resorption has also been observed in ewes during late pregnancy (Smith 1961), although infection at this stage is more likely to have no observable effect on the lambs (Watson \& Beverley). Toxoplasmosis associated with barrenness may be of greater importance than indicated by the present work. However, this may be difficult to demonstrate, as the DT titre may have declined to a level commonly found in latently infected sheep at the time when the ewe proves to be barren. Embryonic or foetal death with resorption might also have taken place in the ewes which returned to service at irregular intervals after the first mating. The importance of toxoplasmosis may be easier to investigate under these conditions than in barren ewes, as high titres are more likely to be found when the ewes return to heat as recorded in 1 flock in the present work.

The predominance of young ewes among those that aborted from toxoplasmosis was not surprising, as the prevalence of infected and thereby immune sheep increases with the age (Waldeland $1977 \mathrm{~b}$ ). This predominance was almost exclusively associated with toxoplasmosis, and this observation alone indicates that T. gondii was the only microorganism of importance in the flocks examined, as other microorganisms known to be of particular importance as abortifacients also induce immunity, and should accordingly also occur with a greater frequency among young ewes than among the older ones.

Symptoms of disease prior to abortion were observed only in the ewes infected with $\mathrm{S}$. montevideo. The symptomless course of toxoplasmosis, apart from abortion, is in accordance with the general conclusions in the available literature.

The normal course of later pregnancies in ewes that aborted from toxoplasmosis is in agreement with studies reported by Watson \& Beverley, but Toxoplasma abortion in the same ewe during 2 succeeding pregnancies has been recorded (Waldeland $1977 \mathrm{~b}$ ). The resistance to reinfection probably also accounts for the negligible loss from toxoplasmosis during later pregnancies 
in these flocks, as the serological examination indicated a high prevalence of Toxoplasma antibodies also among ewes with no abortion.

Studies on the epidemiology of toxoplasmosis in sheep indicated that the frequency of Toxoplasma abortions may be higher in the south-western part of Norway than in other parts of the country (Waldeland $1976 \mathrm{~b}$ ). The present investigation showed that toxoplasmosis was of greater importance as a cause of reproductive loss in sheep in the south-western Norway than in the countries previously referred to. However, this accounts only for the relative importance of the infection. In a 5-year study of sheep in Norway comprising 12093 pregnancies, Nærland \& Helle (1958) found an abortion rate of $1.1 \%$, and $2.7 \%$ of the ewes were barren. About $4 \%$ of the lambs were stillborn or died during the neonatal period. Reports from Great Britain, the United States of America, Australia and New Zealand, of which Watson (1962 b) has given a review, show that the rate of reproductive losis was higher in these countries than in Norway (Nærland \& Helle), probably due to other important abortifacients in adidition to $\mathbf{T}$. gondii.

This investigation showed that toxoplasmosis was the main cause of abortion in sheep. The importance of the infection as a cause of repeat breeding and barrenness is difficult to estimate from the present material, and further work is therefore required to elucidate this.

\section{REFERENCES}

Beverley, J. K. A. \& R. R. Mackay: Ovine abortion and toxoplasmosis in the East Midlands. Vet. Rec. 1962, 74, 499-501.

Beverley, J. K. A. \& W. A. Watson: Ovine abortion and toxoplasmosis in Yorkshire. Vet. Rec. 1961, 73, 6-11.

Beverley, J. K. A. \& W. A. Watson: Further studies on toxoplasmosis and ovine abortion in Yorkshire. Vet. Rec. 1962, 74, 548-552.

Beverley, J. K. A., W. A. Watson \& J. M. Payne: The pathology of the placenta in ovine abortion due to toxoplasmosis. Vet. Rec. 1971 a, 88, $124-128$.

Beverley, J. K. A., W. A. Watson \& J. B. Spence: The pathology of the foetus in ovine abortion due to toxoplasmosis. Vet. Rec. $1971 \mathrm{~b}$, $88,174-178$.

Hartley, W. J. \& B. W. Boyes: Incidence of ovine perinatal mortality in New Zealand with particular reference to intra-uterine infections. N.Z. vet. J. 1964, 12, 33-36. 
Hartley, W. J.\& J. C. Kater: The pathology of Toxoplasma infection in the pregnant ewe. Res. vet. Sci. 1963, 4, 326-332.

Hortemo, Ø. \& J. Øverås: Personal communication 1968.

Jacobs, L. \& W. J. Hartley: Ovine toxoplasmosis: Studies on parasitaemia, tissue infection, and congenital transmission in ewes infected by various routes. Brit. vet. J. 1964, 120, 347 $\longrightarrow 364$.

Kristiansen, F. B. F.: Personal communication 1968.

Munday, B. L.: The epidemiology of toxoplasmosis with particular reference to the Tasmanian environment. Thesis, Univensity of Melbourne, Melbourne 1970.

Nærland, G. \& O. Helle: Unpublished data 1958.

Sabin, A. B. \& H. A. Feldman: Dyes as microchemical indicators of a new immunity phenomenon affecting a protozoan parasite (Toxoplasma). Science 1948, 108, 660-663.

Smith, I. D.: Ovine toxoplasmosis as a cause of reproductive wastage. Preliminary observations. Aust. vet. J. 1961, 37, 18-21.

Stamp, J. T., A. D. McEwen, J. A. A. Watt \& D. I. Nisbeth: Enzootic abortion in ewes. I. Transmission of the disease. Vet. Rec. 1950, $62,251-254$.

Waldeland, H.: Toxoplasmosis in sheep. The reliability of a microtiter system in Sabin and Feldman's dye test. Acta vet. scand. 1976 a, $17,426-431$.

Waldeland, H.: Toxoplasmosis in sheep. The prevalence of Toxoplasma antibodies in lambs and mature sheep from different parts of Norway. Acta vet. scand. $1976 \mathrm{~b}, 17,432-440$.

Waldeland, H.: Toxoplasmosis in sheep. Influence of various factors on the antibody contents. 1977 a. To be published.

Waldeland, H.: Toxoplasmosis in sheep. Long-term epidemiological studies of 4 breeding flocks. $1977 \mathrm{~b}$. To be published.

Waldeland, H. \& J. Øverås: Toxoplasma-abort hos sau. (Toxoplasma abortion in sheep). Medlemsbl. norske Vet.-foren. 1968, 20, $497-500$.

Watson, W. A.: Ovine abortion. Vet. Rec. 1962 a, 74, $1403-1408$.

Watson, W. A.: Abortion and stillbirth in sheep. Part I. Vet. Bull. $1962 \mathrm{~b}, 32,259-264$.

Watson, W. A.\& J.K. A. Beverley: Ovine abortion due to experimental toxoplasmosis. Vet. Rec. 1971, 88, 42-45.

\section{SAMMENDRAG}

Toxoplasmose hos sau. Betydningen av toxoplasmose som årsak til reproduksjonstap hos sau $i$ Norge.

I løpet av perioden $1968-1973$ ble det mottatt diagnosemateriale fra 126 flokker hvor drektighetsforl $\phi$ pet hos enkelte s $\varnothing$ yer avvek fra det normale. I 81 av flokkene ble toxoplasmose diagnostisert. Fra 117 flokker ble det gitt pålitelige opplysninger om antall parrete s $\varnothing$ yer og om drektighetsforl $\varnothing$ pet. I disse flokkene med i alt 7812 parrete s $\varnothing$ yer var det 858 søyer som ikke fikk levedyktige lam. Omkring $80 \%$ av dette tapet ble tilskrevet toxoplasmose, $4 \%$ skyldtes bakterielle infek- 
sjoner, og i ca. $16 \%$ av tilfellene var det ikke-infeksjøse og/eller ikke påviste årsaker.

Tapsfrekvensen i den enkelte flokk var høyest ved toxoplasmose

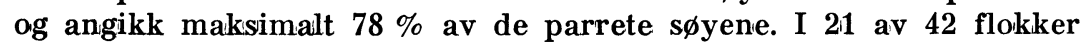
med minst 20 s $\varnothing$ yer og en h $\varnothing$ y tapsfrekvens $(\geq 10 \%)$ som følge av Toxoplasma-infeksjon, var tapet over $20 \%$, mens et så stort tap bare forekom i 1 av 13 flokker $i$ forbindelse med andre årsaker.

Toxoplasmose hadde betydning ikke bare som abortårsak, men også som årsak til omløp, infertilitet, forekomst av dødfødte lam og av svake lam som døde.

Hvite flekker ble påvist $\mathrm{i}$ cotyledonene på omkring to tredjedeler av fosterhinnene ved Toxoplasma-abort. Det ble ikke funnet holdepunkter for at slike forandringer opptrer ved andre abortårsaker.

Abortfrekvensen var h $\varnothing$ yere blant unge sфyer enn blant de eldre. Søyene viste ikke kliniske symptomer på Toxoplasma-infeksjon f $\varnothing \mathbf{r}$ de aborterte, og drektigheten forl $\varnothing p$ normalt senere år.

(Received September 27, 1976).

Reprints may be requested from: Harald Waldeland, the State Veterinary Research Station for Small Ruminants, Postboks 248, 4301 Sandnes, Norway. 